\title{
EXTENSIVE LISTENING: LET STUDENTS EXPERIENCE LEARNING BY OPTIMIZING THE USE OF AUTHENTIC MATERIALS
}

\author{
Yulia Hapsari \\ Devinta Puspita Ratri \\ Fakultas Ilmu Budaya, Universita Brawijaya, Malang \\ Address: Jl. Veteran, Malang 65145 Telp +62-341-575875 \\ E-mail: hapsari.yulia@ub.ac.id
}

\begin{abstract}
In a country like Indonesia, one of challenges in learning English as a foreign language is a lack of exposure of English in its authentic sense. The use of authentic materials seems to be an option to cope with this situation. One of the ways to optimize the use of the authentic materials to trigger students to experience learning and to enhance their active involvement in the learning process is by using it in extensive listening activities. Through extensive listening by using authentic materials, students are exposed to real native speech in meaningful language use. As the result, difficulties in listening gradually disappear. In order to put the idea into practice, the first thing to do is to set objectives of each meeting based on core vocabulary and grammar that are suitable for the learners using comprehensible input principle as the basic consideration. Second, selecting authentic materials that suit the objectives and that give exposure to formulaic language and meaningful language use. Then, preparing activities in which the instruction is reasonable and lead to sufficient practice to develop fluency. Finally, synchronize teaching activities to increase students' motivation to learn. As a follow up activities, students are informed and eventually involved in the whole process. Thus, students experience learning and actively involved in their learning process.
\end{abstract}

Keywords: extensive listening, authentic material, experience learning, active involvement

\begin{abstract}
Abstrak
Di negara seperti Indonesia, salah satu tantangan dalam pembelajaran Bahasa Inggris sebagai bahasa asing adalah kurangnya pemaparan penggunaan bahasa Inggris tersebut dalam makna sebenarnya. Salah satu jalan keluar yang mungkin dilakukan adalah dengan menggunakan materi pembelajaran yang otentik. Materi pembelajaran yang otentik ini sebaiknya digunakan seoptimal mungkin untuk memancing siswa untuk mengalami sendiri pembelajaran dan mendorong keterlibatan aktif mereka dalam proses pembelajran yang mereka alami. Salah satu caranya adalah dengan memanfaatkannya dalam kegiatan menyimak lanjutan. Melalui menyimak lanjutan dengan menggunakan materi pembelajaran yang otentik, siswa dipaparkan pada kebermaknaan pembicaraan penutur asli dalam konteks penggunaan bahasa Inggris yang sebenarnya. Sebagai hasilnya, kesulitan-kesulitan yang dialami siswa dalam aktifitas menyimak perlahan-lahan menghilang. Untuk menerapkan gagasan tersebut dalam praktek nyata di dalam kelas, hal pertama yang
\end{abstract}


perlu dilakukan adalah menetapkan tujuan pembelajaran di setiap pertemuan yang didasarkan pada kosakata dan tata bahasa yang sesuai dengan siswa menggunakan prinsip masukan yang dapat dipahami sebagai pertimbangan utamanya. Kedua, menyeleksi materi pembelajaran otentik yang sesuai dengan tujuan pembelajran yang telah ditetapkan dan yang dapat memberi pemaparan pada penggunaan ungkapanungkapan dalam prinsip kebermaknaan penggunaan bahasa. Langkah berikutnya adalah menyiapakan kegiatan-kegiatan belajar mengajar dengan instruksi-instruksi yang masuk akal dan mengarah kepada adanya latihan-latihan yang mencukupi untuk meningkatkan kelancaran siswa dalam melakukan kegiatan menyimak. Akhirnya, kegiatan-kegiatan belajar mengajar tersebut dipadukan sedemikian rupa sehingga memotivasi siswa untuk terus belajar. Sebagai kegiatan lanjut, siswa diberitahu tentang pertimbangan-pertimbangan yang dipakai dalam penyusunan kegiatan belajar mengajar yang telah dilakukan dan pada akhirnya dilibatkan pada persiapan dan pelasanaan keseluruhan proses. Dengan demikian, siswa mengalami sendiri pembelajarannya dan terlibat secara aktif dalam setiap tahapannya.

Kata-kata kunci: Menyimak lanjut, materi otentik, pengalaman belajar, keterlibatan aktif

\section{INTRODUCTION}

Learning a new language using mostly the target language seems intimidating to most learners, yet it is much more effective than learning it through learners' first language. Learning a new language without getting more opportunity to be exposed and to use it is like cooking with no tools except a cook book. Teachers have differing views on the use of L1 in the classroom, especially if it is a monolingual class. However, if the teacher starts teaching the new language using L1, the authenticity of the target language will be lost. Renandya suggested eight factors that are fairly uncontroversial and are believed to play a critical role in the development of EFL threshold level. Those factors are sufficient amount comprehensible input, opportunity for meaningful language use, sufficient motivation to learn, attention to the development of core vocabulary and grammar, sufficient practice to develop fluency in receptive skills, exposure to formulaic language and reasonable intensity of instruction (Renandya, 2013).

Learning English as a foreign language in a country like Indonesia emerging a challenge for English Department students due to lack exposure of the language in its authentic sense. Exposure of target language is essential in learning foreign language in order to get students experience a real use of the language. Among language skills -reading, listening, speaking, and writing- listening is one of the hardest activities for most students (Riddell, 2003). Therefore, Field (in Richards and Renandya, 2002) advised that authentic materials should be introduced in listening activities in the early stage of language learning due to two reasons: naturalness of language and real-life-listening experience.

Listening is significant in language course since it gives input for the students. Right level of input will help students to begin to understand the language. There are three reasons for emphasizing listening as stated by Rost (in Nunan, 1999). First, 
learners must interact to achieve understanding of spoken language. Therefore access to speakers of the language is essential. Learners' failure to understand the language they hear is an impetus, not an obstacle, to interaction and learning. Second, authentic spoken language presents a challenge for the learner to attempt to understand language as native speakers actually use it. Finally, listening exercises provide teachers with the means for drawing learners' attention to new forms (vocabulary, grammar, new interaction patterns) in the language.

Listening activities can benefit from the use of authentic materials as they are needed as a potential solution to students' problems in comprehending speech in reallife context. Comprehending natural real-life English is important for English learners since it brings accent, speed, and meaning as stated by Field (in Richard and Renandya, 2002). Listening experience and meaningful language use can be provided for the students through the use of authentic passages since it is closer to everyday use of the language. Field (in Richard and Renandya, 2002) suggested that authentic materials should be introduced early to language learners to give practice and exposure in order to get naturalness of language and real life listening experience.

However, authentic materials generally make students daunted. In a natural-sounding recording taken from a real use of English, there is ungraded language. Voices, accents, and maybe dialects will be new to students. Often the conversation in the recording is, or seems, fast. These aspects may cause a 'shock' to the students. Coping with this challenge, students need to be informed not to expect to understand every detail of the script. Field explained further that there are three phases of getting the most from listening to authentic material that non-native listeners might do. First, identify words in few fragmented sections of the text. Feel relatively certain about some, less certain about others. Then make inferences linking the parts of the text about which you feel most confident, and finally check those inferences against what comes next (Richard and Renandya, 2002).

Students' fluency can also be developed using authentic materials as argued by Lam (in Richard and Renandya, 2002) because it is highly possible for the authentic materials to contain fixed and conventional phrases that are able develop students' fluency. Fluency here has connection with memorized sequences lexicalized sentence stems which are included in formulaic language use (Pawley \& Syder in Richard and Renandya 2002). By getting use to and understanding formulaic language used in authentic materials, students' problem in real-life communication will be lessened. Thus, authentic materials in listening should be given as extensive listening activities as learners who learn through extensive reading/listening tend to achieve a higher level of proficiency in English (Day and Bamford, 1998; Renandya, 2011).

Taking the problems that challenge the learners of English as a foreign language as well as the benefits of the use of authentic materials into account, the researchers decided to conduct a classroom action research by using authentic materials in extensive listening activities. The research is performed to a listening class of first semester students majoring in English in Language and Literature Department Universitas Brawijaya Malang in response to the students' problems in listening activity identified through a survey prior to teaching and learning activity of the class. 


\section{METHOD}

Under this heading, research method of the present study is described in order to give a clear idea about the methodological aspects employed. This chapter discusses the research design, the setting and subject of the research, the action research procedure, the implementation, and the reflection of the action.

The design of this study is action research as it addresses listening problems faced by students' in on of the researchers' listening classroom and it searches solutions to the problem. This framework is in line with what is stated by Creswell (2012) who argued that action research addresses a specific, practical issue and seeks to obtain solutions to a problem. Thus, action research designs are systematic procedures done by teachers (or other individuals in an educational setting) to gather information about, and subsequently improve, the ways their particular educational setting operates, their teaching, and their student learning ( Mills, 2011 ).

The design was chosen since it deals with the specific or local issues in classroom setting and the study was aimed at solving the research' subjects' problem in listening revealed from preliminary study conducted prior to implementing the research. These problems are related to accent, vocabulary, speed and length in listening to real-life context activities in listening class. To cope with the problems, the researchers make use of authentic materials to give more exposure and real-life listening experience as well as to involve the students in their learning process so that they experience learning.

The researchers decided to use a design of action research viewed by Mills (2011) that consists of four steps; identify an area of focus, develop an action plan, collect data, and analyze and interpret data. The decision is based on practicality and feasibility of the design to be applied in the listening class. The design forms a cyclical process that can be seen in Figure 1.

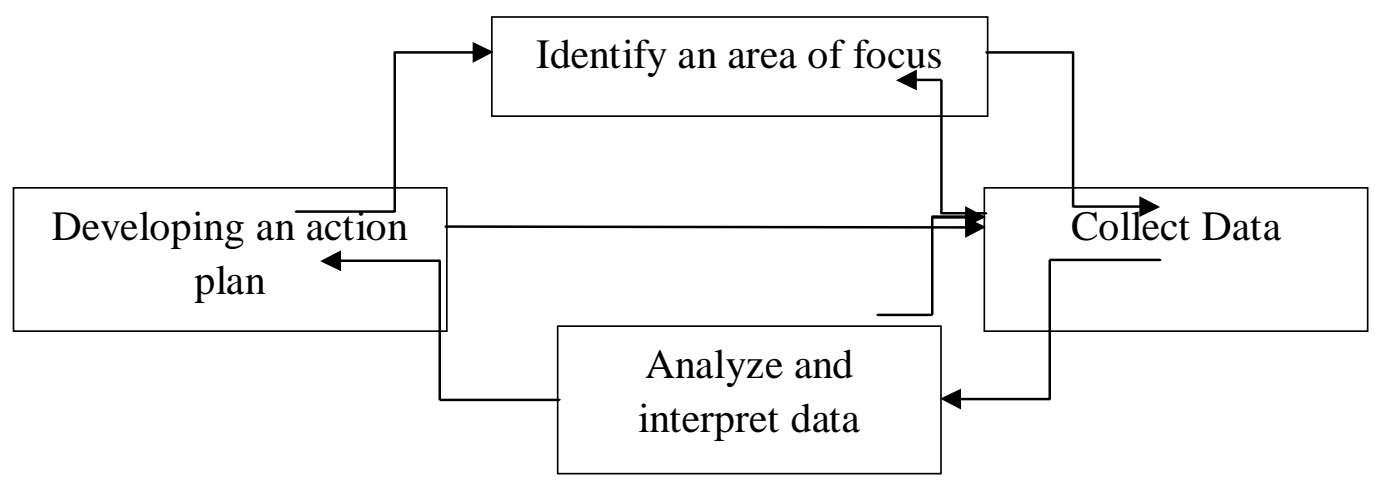

Figure 1. Action Research Steps (Adapted from Mills, 2011)

The research was conducted in one listening class of first semester students majoring in English in Language and Literature
Department Universitas Brawijaya. In this department, there are five parallel classes of first semester students. The students get two 
kinds of listening classes namely English Clause Level Listening class and English Above Clause Level Listening class at the same semester. The research took place in one of the five English Above Clause Level Listening parallel classes which consists of 35 students. It is one of the researchers' own class. The class is designed to equip the students with listening skill so that the students are able to fit themselves in any spoken discourse both receptively and productively. The content of the course is emphasized more on the ability to listen to utterances both in sentence level and in long discourse focusing on the understanding of the main idea and specific spoken discourse.

Five basic steps constructing the procedure of the research are implemented after a preliminary study carried out to identify students' problems in listening. The preliminary study, conducted prior to teaching-learning activities of the class, is executed through a survey in which students are to respond to a set of questionnaires to reveal students' problems in listening and their frequency of exposing themselves to listen to English utterances and spoken discourse. Then the researchers discuss the finding of the preliminary study to find a possible solution. The solution chosen is manifested in an action plan which consist five basic steps. The first step is setting objectives of the classroom teaching. After that, authentic teaching materials for listening skill which are suitable to students' level of proficiency are selected. This selection leads to the next steps; preparing activities in which the instruction is reasonable and lead to sufficient practice to develop fluency, and synchronizing the activities into interesting teaching learning activities that motivate students to learn. Finally, the last step is to involve the students to prepare teaching-learning materials and execute them in the classroom.

During the implementation of the action plan, the researchers collect data by observing any changes happen to the class and to the students related to students' listening skill. In the end of the action plan execution, data are also collected by handing out a set of questinnaire. The data collected from the observation and questionnaire are analyzed descriptively and interpreted to find out changes happen to students' listening skill and their frequency of exposing themselves to listen to English utterances and spoken discourse.

\section{RESULTS AND DISCUSSION}

Later in this discussion data obtained from the preliminary study and the implementation of the action plan as well as their analysis, discussion, and interpretation are presented.

The following is a description of the preliminary study and each step along with observations to students' reactions throughout the process.

\section{Preliminary Study}

The purpose of the preliminary study is to find out students' problems in listening activity and their frequency in exposing themselves to listen to English spoken discourse. Data derived from this phase serve as the basis to arrange an action plan aimed at finding solution to the problems. In order to do so, a survey was carried out to students from one of the five English Above Clause Level Listening parallel classes that became the subject of the research. The students completed a set of questionnaire to identify their problems in listening and their frequency in listening materials in English. Table 1 lists the problems identification and the students' responses. 
Table 1. Students' Problems in Listening

\begin{tabular}{lll}
\hline Problem in listening & Yes & No \\
\hline Accent & 23 & 12 \\
Speed & 14 & 21 \\
Vocabulary & 23 & 12 \\
\hline Length & 8 & 27 \\
\hline
\end{tabular}

The problems identification responses showed that around $65 \%$ of the students had problems related to accent; mostly because of accents that were considered strange to them. Around $65 \%$ of the students admitted to have problem in vocabulary. Some of the students stated that some accents that sound strange to them prevented them from identifying vocabulary that actually was not new to them. Few of the students stated that they often found vocabulary which was new to them and was difficult to guess only by listening to the spoken discourse especially when the vocabulary was pronounced with an accent that sounds strange to them. Other argued that although they had a correct guessing of the vocabulary, they still had difficulties in understanding the spoken discourse because they did not understand the meaning of the vocabulary. In other words, it was their limited vocabulary that put them in difficulties, not the accent. $40 \%$ of the students found difficulties related with the speed of the listening materials. Their arguments are varied. Few students said that sometimes listening materials with American accent that they listened to were just too fast so that they could not really understand the whole content of the spoken discourse. In addition, most students stated that when the speed of the listening materials they listened to is too fast they could not catch the words being said, it is confusing and in some cases it felt like they only heard buzzes sound. Around 22\% of the students stated that the length of the listening materials put them in difficulties. Some listening materials which were considered long made these students lost their focus, and it made them having difficulty in taking points because there were just too many points to memorize. From these responses it can be ranked that the students' problems in listening are mostly caused by accent, vocabulary, speed, and length of the listening materials in its order respectively.

Do students have adequate exposure to listening English materials? To find out, students were presented statements pertaining to their English listening activity and asked to rate the statements using a Likert Scale. Table 2 lists the statements and the responses.

Table 2. Students' Exposure to Listening English Materials

\begin{tabular}{llllll}
\hline & Always & Often & Seldom & Rarely & Never \\
\hline $\begin{array}{l}\text { Frequency of listening to English outside the } \\
\text { classroom }\end{array}$ & 10 & 9 & 9 & 7 & 0 \\
$\begin{array}{l}\text { Frequency of listening to English accent } \\
\begin{array}{l}\text { American } \\
\text { British }\end{array}\end{array} \quad 29$ & 6 & 0 & 0 & 0 \\
& 0 & 6 & 18 & 10 & 0 \\
\end{tabular}


Indonesian

Others

The responses showed that 7 students rarely listened to English outside their classroom and 9 others seldom did it as well. It can be interpreted that around $46 \%$ of the students had not had high frequency in exposing themselves to English listening materials outside the classroom. On the other hand, $54 \%$ of the students indicated that they had relatively high frequency in listening to English outside their classroom. The result of the survey also indicated that all students had relatively high frequency in exposing themselves to American accent. However, only $20 \%$ of the students had relatively high frequency in listening to British accent as $80 \%$ others either hardly exposed themselves to it. While all students stated that they always listened to English with Indonesian accent, other accents except Indonesian, the finding of the preliminary study indicated that around $72 \%$ of the students never listened to other accents except American, British and Indonesian, while $28 \%$ others did. This data presented strong indications that students did not have enough exposure of various accents of English relates to their listening activity.

Students also responded to openended questions on the survey. The overwhelming response to the question, "What is the resource of your English listening material?" was from their teachers and classmates. Other resources are from listening materials at school, songs and movies. When asked, "Is it important to you to expose yourself to various accents? Why" most students responded that it is important for them to expose themselves to various accents of English, especially American accent as in many listening materials at
35

0
0

0
0

3
0

7
0

25

school and in some standardized tests, in this case these tests refer to TOEFL and TOEIC, American accent is the one that is mostly used. Some students, on the other hand, also stated that British accent is also important although it is not as important as American accent for British accent often appear in their listening materials at school but not in the two standardized tests. The next important accents mentioned are varied from Singaporean, Australian, and Indian English. The students responding so argued that they need to understand those accents as they often encounter interlocutors using the accents. While most students argued that exposing themselves to various accents of English is important, few others stated that it is not important as long as they are familiar with American accent as it is the one widely used and understood by most people in the word. Surprisingly, no students responded that Indonesian accent is important. When they were asked of the reason, the students stated that they are already familiar with the accent and barely have problem with it, not to mentioned that Indonesian accent is not widely used either in their listening materials at school or in the two standardized tests.

From the data gathered from the survey in the preliminary study, the researchers, then, had discussions on the possible solution to help the students minimize their problems in listening. The researchers believe that the students' problem with some English accent is due to the lack of exposure of the accents, and the students' problem with vocabulary can be lessen by giving them meaningful language use in which formulaic language use is 
almost inevitable to be involved. The discussions led to a decision that an extensive listening using authentic material is considered to be the most appropriate way to help the students encounter their problems in listening. As most students do not have any problem with the length of the listening materials, the researcher decided to add the length of the listening materials gradually by putting comprehensible input principle into account. Then, in coping with some students' problem related to the speed of the listening materials, researchers agreed to start the teaching-learning activity from listening materials having slow pace and end it with faster ones.

\section{Action Plan}

Action plan is formulated to provide a solution to students' problem in listening. It consists of five basic steps; the first thing to do is to set objectives of each meeting based on vocabulary and grammar that are suitable for the learners using comprehensible input principle as the basic consideration. Second, selecting authentic materials that suit the objectives and that give exposure to formulaic language and meaningful language use. Then, preparing activities in which the instruction is reasonable and lead to sufficient practice to develop fluency. Next, synchronize teaching activities to increase students' motivation to learn. As a final activity, students are informed and eventually involved in the whole process of preparing and using listening materials. Thus, students experience learning and actively involved in their learning process.

\section{Step 1. Setting Objectives}

An activity to get information of students' vocabulary was performed in the first meeting. The students were asked to write down as much vocabulary as possible in a limited time. First, students were asked to write down any nouns in English in three minutes. Then, given the same amount of time, students were asked to write down any verbs in English. The same activity was continued for adjective and adverb. It was revealed, from students' response, that the students were able to write down noun more than verb, followed by adjective and adverb. The students did not make any mistake in identifying noun. Yet, some mistakes occurred when they need to identify verb, adjective and adverb. Some students mistakenly wrote down adjective when they were supposed to write verb. Some others wrote down adjective when they should write adverb. These data implied that the students have a good understanding about noun and adequate vocabulary of it. On the other hand, the students needed to improve both their vocabulary and understanding in adjective, verb, and adverb. Their improvement in adjective should come first before adverb, verb, and noun, respectively.

Information about students' knowledge of grammar was derived from observation of students' spoken discourse during the first meeting. Students were asked to introduce themselves and talk briefly about their unforgettable experience as a manifestation of mingling activity. Most students had to struggle with their vocabulary and grammar as they spoke. Some survived the simple present tense; some others kept making mistake either in the use of third person singular verbs or in producing verbal and non-verbal utterances. When it came to telling their unforgettable experience, most students lost their grammar control. Their past and perfect tenses concept seemed to jump here and there. This 
situation implied that grammar focus needs to be inserted in students' listening activity.

Having the data of students' vocabulary and grammar mastery, the researchers came to a decision that the students should get authentic listening materials which give exposure more on adjective, adverb, verb, and noun as well as grammar use started from the simple present, simple past, present continuous, past continuous, and future expressions. This decision was taken by placing significant attention to providing comprehensible input for the students. These aspects were then formulated to set objectives of the course.

\section{Step 2. Selecting Materials}

Authentic materials that possibly suit the objectives of the course were compiled. These materials were taken from various sources such as books, internet, and CDs both audio and video ones. They were also varied in forms; short dialogues, songs, videos, and movies. Then, the materials were arranged into a continuum started from the simplest to the most complex ones using vocabulary and grammar focus as the basic consideration. From each category, the materials were selected and grouped by putting the accent, speed, and length of the materials into account.

\section{Step 3. Preparing Activities}

Reasonable instructions that allow the students to be actively involved in the learning process either as individual or member of the class became the main attention in preparing the activities. As listening is mostly a private activity in an understanding that each individual may react and perform differently toward the same listening materials, the researchers decided to apply various activities that are suitable to explore and make the most from the materials as well as that require students' focus. These activities include dictation, cloze passage, re-stating ideas, and answering comprehension questions.

\section{Step 4. Synchronizing Teaching Activities}

In this research, researcher as a teacher, then synchronize activities that were going to be used in each meeting. For every meeting, materials along with their activities were selected based on the objective of the meeting. The activities were then arranged in a way that the teaching-learning process would run well and attract students' interest and motivation. This arrangement should be done in a sequence in which simple activity with relatively easy material was performed first before the more complex activity or more challenging material was given.

\section{Step 5. Students Work}

In every meeting, after the teachinglearning activities were executed, the teacher as researcher invited the students to reflect back to what they had done in that meeting. This reflection was conducted in a relax way as it was a sharing situation. At first, the teacher asked what the first material that was given to them, and what activities they did using the material. It was to find out whether or not the students paid attention to what they got and what they did. Then students were asked about the possible reasons why the teacher did that; what was the goal of applying such activities using such material, and what they had learnt from it. It was done to elicit the rationale behind each activity so that the students were informed and aware of their learning process.

After several meetings, when the students seemed to be aware of their learning process they were going through, 
they were asked to work in a group of three. In this group, they were assigned to prepare listening materials and possible activities that are suitable to be applied using the material. The next thing they did was to use the materials in the classroom as if they were the teacher. Each group was given thirty minutes to execute their action. After their performance, feedback was given both by the teacher and the other students only to know whether the group's objective was achieved or not and the possible causes of it. This activity was done to make the students experience learning and actively involved in their learning process since the students needed to set their goal of learning before they explored many listening sources to get an appropriate listening material suitable for their goal. Moreover, in the process of matching the material they got with possible activities students needed to expose themselves to the listening again and again.

\section{CONCLUSION AND SUGGESTION}

The classroom action research helped the researchers to find a potential solution to overcome the students' problem in listening which mainly relates to various accent of English, students' limited vocabulary, the speed and length of the listening materials. Beside the benefits that can be derived from the use of authentic materials, involving students to experience learning is really important to make them aware and actively take part in their learning process. Thus, not only their problems that can gradually disappear inline with their improvement in their listening skill, but students' understanding about their learning process is also improved.

\section{ACKNOWLEDGMENTS}

We would like to express our sincere gratitude to journal Bahasa \& Sastra for publishing this article, and the same goes to those who have helped this research.

\section{REFERENCES}

Creswell, J.W. (2012). Educational Research: Planning, Conducting, and Evaluating Quantitative and Qualitative Research. $4^{\text {th }}$ Edition. Boston: Pearson Education Inc.

Day, R. \& Bamford, J. (1998). Extensive Reading in the Second Language Classroom. Cambridge:

Cambridge University Press.

Mills, G.E. (2011). Action Research: A Guide for the Teacher Researcher. $4^{\text {th }}$ Edition. Upper Saddle River: Pearson/Allyn \& Bacon.

Nunan, D. (1999). Second Language Teaching and Learning. Boston: Heinle \& Heinle Publishers.

Renandya, W.A. (2011). Extensive listening in the second language classroom. In Widodo, H.P., \& Ciroki, A. (Eds.), Innovation and Creativity in ELT Methodology (pp.28-41). New York: Nova Science Publishers. (2013). Current Beliefs in ELT and Their Implications for Language Teaching. Plenary Paper presented at the International TEFL Conference, May 18. 2013. Surakarta, Indonesia.

Richards, J. \& Renandya, W.A..(2002). Methology in Language teaching: An Anthology of Current Practice. Cambridge: Cambridge University Press.

Riddell, D. (2003). Teaching English as a Foreign Language. London: Hodder Headline Ltd. 
bahasa \& sastra, Vol. 14, No.2, Oktober 2014 